\title{
PEMAHAMAN MAHASISWA DALAM ANALISIS MATERI DENGAN MENGGUNAKAN METODE DRILLING YANG BERORIENTASI PADA PENDEKATAN KONTEKSTUAL PADA MATA KULIAH PERENCANAAN PEMBELAJARAN
}

\author{
Wahyu Susiloningsih \\ Prodi PGSD, FKIP, Unipa Surabaya \\ wahyulou 242@yahoo.co.id
}

\begin{abstract}
Abstrak
Artikel ini mendeskripsikan pemahaman mahasiswa dalam analisis materi dengan menggunakan metode drilling yang berorientasi pada pendekatan kontekstual pada mata kuliah perencanaan pembelajaran. Metode pembelajaran dapat diartikan sebagai cara yang digunakan untuk mengimplementasikan rencana yang sudah disusun dalam bentuk kegiatan nyata dan praktis untuk mencapai tujuan pembelajaran. Metode Drill merupakan suatu cara mengajar dengan memberikan latihan-latihan terhadap apa yang telah dipelajari mahasiswa sehingga memperoleh suatu keterampilan tertentu.Pemahaman merupakan satu proses yang dapat terlihat dari hasil belajar dimana suatu proses perubahan tingkah laku dalam pengetahuan, sikap, dan ketrampilan yang diperoleh dalam jangka waktu yang lama. Analisis materi, sebelum mentransformasikan materi pembelajaran kepada peserta didik, terlebih dahulu perlu dilakukan analisis materi pembelajaran semata-mata agar pembelajaran lebih bermakna.

Penelitian ini termasuk penelitian kuantitatif deskriptif. Subjek dalam penelitian ini adalah mahasiswa PGSD UNIPA angkatan 2016 kelas C. Teknik pengambilan data yang digunakan adalah observasi lembar keterlaksanaan RPP dan tes. Data yang terkumpul akan dianalisis secara statistik dan kemudian di deskriptifkan. Hasil analisis di interpretasikan sehingga menghasilkan kesimpulan sesuai dengan permasalahan dalam penelitian ini.

Hasil penelitian yang diperoleh dari tes hasil perkuliahan mahasiswa sebelum menggunakan metode drilling menunjukkan nilai rata-rata 70 dengan kategori baik. Selanjutnya tes hasil perkuliahan mahasiswa setelah menggunakan metode drilling yang berorientasi pada pendekatan kontesktual menunjukkan nilai rata-rata 90.

Dari hasil tersebut dapat disimpulkan bahwa terdapat peningkatan pemahaman mahasiswa yang diukur melalui tes hasil belajar sebelun dan sesudah menggunkan metode drilling yang berorientasi pada pendekatan kontekstual
\end{abstract}

Kata kunci: Metode drilling, Pemahaman (Hasil Belajar), Analisis Materi

\begin{abstract}
This article describes the understanding of students in material analysis using the drilling method that is oriented towards a contextual approach to learning planning courses. Learning methods can be interpreted as ways that are used to implement plans that have been prepared in the form of real and practical activities to achieve learning goals. Drill method is a way of teaching by giving exercises to what students have learned so that they obtain a certain skill. Understanding is a process that can be seen from learning outcomes where a process changes behavior in the knowledge, attitudes, and skills acquired in the term long time. Material analysis, before transforming learning material to students, it is first necessary to analyze learning material solely so that learning is more meaningful.
\end{abstract}


This research includes descriptive quantitative research. The subjects in this study were class C. UNIPA PGSD class 2016 students. The data collection technique used was observation of the lesson plan and test implementation. The collected data will be analyzed statistically and then described. The results of the analysis are interpreted so as to produce conclusions according to the problems in this study.

The results of the research obtained from the test results of student lectures before using the drilling method showed an average value of 70 in the good category. Furthermore, the test results of student lectures after using the drilling method oriented to the contestual approach show an average value of 90 .

From these results it can be concluded that there is an increase in students' understanding which is measured through learning outcomes tests before and after using the drilling method oriented to the contextual approach.

Keywords: Drilling Method, Understanding (Learning Outcomes), Material Analysis

\section{PENDAHULUAN}

Proses belajar mengajar atau Dalam Undang-Undang No.20 Tahun 2003 Tentang Sistem Pendidikan Nasional pasal 1 ayat 20 dinyatakan bahwa Pembelajaran adalah Proses interaksi peserta didik dengan pendidik dan sumber belajar pada suatu lingkungan belajar.

Konsep pembelajaran menurut Corey (Syaiful Sagala, 2011:61) adalah suatu proses dimana lingkungan seseorang secara disengaja dikelola untuk memungkinkan ia turut serta dalam tingkah laku tertentu dalam kondisi-kondisi khusus atau menghasilkan respons terhadap situasi tertentu, pembelajaran merupakan subset khusus dari pendidikan.

$$
\text { Dapat disimpulkan bahwa }
$$

pembelajaran adalah proses interaksi peserta didik dengan pendidik dan sumber belajar pada suatu lingkungan belajar yang dilakkan secara sadar dan terencana. Untuk mencapai suatu pembelajaran yang optimal dimana tujuan pembelajaran dapat tercapai, maka guru perlu melakkan persiapan baik media, bahan ajar ataupun metode yang akan dignakan dalam proses pembelajaran.
Namun pada kenyataannya mahasiswa PGSD 2015 pada mata kuliah Perencanaan Pembelajaran banyak yang kurang memahami dalam pokok bahasan analisis materi pada buku siswa. Hal ini terbukti pada hasil presentasi dan pengisian lembar kerja mahasiswa. Dari hasil presentasi dimana mahasiswa kesulitan dalam menentukan suatu tujuan pembelajaran tersebut termasuk materi konseptual, faktual, procedural, atau metakognitif. Dalam hal ini dibutuhkan ketrampilan khusus dalam kepekaandan analisis mendalam untuk menentukan suatu tujuan pembelajaran tersebut. Karenanya peranan seorang pendidik sangat dibutuhkan untuk meningkatkan pemahaman mahasiswa dalam menganalisis materi pada mata kuliah perencanaan pembelajaran serta mencapai suatu proses pembelajaran yang berkualitas.

Pembelajaran Latihan Drill merupakan suatu cara mengajar dengan memberikan latihan-latihan terhadap apa yang telah dipelajari mahasiswa sehingga memperoleh suatu keterampilan tertentu. Kata latihan mengandung arti bahwa sesuatu itu selalu diulang-ulang, akan tetapi bagaimanapun juga antara situasi belajar yang pertama dengan situasi 
belajar yang realistis, mahasiswa akan berusaha melatih keterampilannya. Bila situasi belajar itu diubah-ubah kondisinya sehingga menuntut respons yang berubah, maka keterampilan akan lebih disempurnakan.

Sehingga mahasiswa angkatan 2016 pada mata kuliah perencanaan pembelajaran dalam pokok bahasan analisis materi, peneliti berinisiatif menggunakan metode yang belum pernah dilakukan sebelumnya, yakni metode drilling (latihan). Penggunaan metode drilling bermaksud untuk meningkatkan pemahaman mahasiswa dalam analisis materi mata kuliah perencanaan pembelajaran. Memahami apa yang mahasiswa ikuti selama proses perkuliahan, sehingga diketahui penerapan metode drilling bermaksud untuk meningkatkan pemahaman mahasiswa dalam analisis materi mata kuliah perencanaan pembelajaran.

\section{KAJIAN LITERATUR}

Metode Pembelajaran

Metode pembelajaran dapat diartikan sebagai cara yang digunakan untuk mengimplementasikan rencana yang sudah disusun dalam bentuk kegiatan nyata dan praktis untuk mencapai tujuan pembelajaran.

Dalam proses pembelajaran dikenal beberapa istilah yang memiliki kemiripan makna, sehingga sering kali orang merasa bingung untuk membedakannya. Istilah-istilah tersebut adalah: (1)Pendekatan Pembelajaran, (2)Strategi Pembelajaran, (3)Metode pembelajaran, (4)Teknik pembelajaran, (5)Taktik Pembelajaran, (6)Model Pembelajaran.
Pendekatan Pembelajaran dapat diartikan sebagai titik tolak atau sudut pandang kita terhadap terjadinya suatu proses yang sifatnya masih sangat umum, di dalamnya mewadahi, menginspirasi, menguatkan, dan melatari metode pembelajaran dengan cakupan teoritis tertentu (Komalasari, 2010:54)

Sementara itu pendekatan pembelajaran merupakan suatu himpunan asumsi yang saling berhubungan dan terkait dengan sifat pembelajaran. Suatu pendekatan bersifat aksiomatik dan menggambarkan sifat-sifat dan ciri khas suatu pokok bahasan yang diajarkan (Suyono dkk, 2011:18).

Ketika orang akan mengerjakan sesuatu, maka orang tersebut mestinya menetapkan sasaran yang hendak dicapai. Untuk mencapai sasaran itu seseorang memilih pendekatan yang tepat sehingga diperoleh hasil yang optimal, berhasil, guna dan tepat guna.

Dari pendekatan pembelajaran yang ditetapkan selanjutnya diturunkan dalam strategi pembelajaran. Newman dan Logan (Komalasari, 2010:54) mengemukakan empat unsur strategi dari setiap usaha, yaitu:

Mengidentifikasi dan menetapkan spesifikasi serta kualifikasi hasil (output) dan sasaran (target) yang harus dicapai, dengan mempertimbangkan aspirasi dan selera masyarakat yang memerlukannya.

Mempertimbangkan dan memilih jalan pendekatan utama (basic way) yang paling efektif untuk mencapau sasaran.

Mempertimbangkan dan menetapkan langkah-langkah (step) yang akan ditempuh sejak titik awal sampai dengan sasaran.

Mempertimbangkan dan menetapkan tolak ukur (criteria) dan patokan ukuran 
(standart) untuk mengukur dan menilai taraf keberhasilan (achievement) usaha.

Jika kita terapkan dalam konteks pembelajaran, keempat unsur tersebut adalah:

Menetapkan spesifikasi dan kualifikasi tujuan pembelajaran yakni perubahan profil prilaku dan pribadi peserta didik

Mempertimbangkan dan memilih sistem pendekatan pembelajaran yang dipandang paling efektif.

Mempertimbangkan dan menetapkan langkah-langkah atau prosedur, metode dan teknik pembelajaran.

Menetapkan norma-norma dan batas minimum ukuran keberhasilan atau kriteria dan ukuran baku keberhasilan.

Selanjutnya, metode pembelajaran didefinisikan sebagai cara yang digunakan guru, yang dalam menjalankan fungsinya ,erupakan alat untuk mencapai tujuan pembelajaran (Aqib, 2013:70)

Metode pembelajaran adalah seluruh perencanaan dan prosedur maupun langkah-langkah kegiatan pembelajaran termasuk pilihan cara penilaian yang akan dilaksanakan (Suyono dkk, 2011:18)

Secara umum metode diartikan sebagai suatu cara melakukan sesuatu. Secara khusus, metode pembelajaran dapat diartikan sebagai cara atau pola yang khas dalam memanfaatkan berbagai prinsip dasar pendidikan. Selain itu, metode juga merupakan berbagai teknik dan sumber daya terkait lainnya agar terjadi proses pembelajaran pada diri peserta didik.

Dengan demikian, teknik pembelajaran dapat diartikan sebagai cara yang dilakukan seseorang dalam mengimplementasikan suatu metose secara spesifik (Komalasari, 2010:56)
Teknik pembelajaran adalaj jalan, alat, atau media yang digunakan oleh guru untuk mengarahkan kegiatan peserta didik kearah tujuan yang ingin dicapai, Gerlach dan Ely (Aqib, 2011:70)

Misalnya, penggunaan metode ceramah dalam kelas dengan jumlah siswarelatif banyak membutuhkan teknik tersendiri, yang tentunya secara teknis akan berbeda dengan penggunaan metode ceramah pada kelas yang jumlah siswanya terbatas. Dengan kata lain teknik pembelajaran adalah implementasi dari metode pembelajaran yang secara nyata berlangsung di dalam kelas.

Ada beberapa macam metode pembelajaran, diantaranya:

\section{Metode ceramah}

Metode ceramah adalah metode belajar mengajar secara tradisional, sebab metode pembelajaran ini telah gunakan sebagai alat komunikasi lisan antara guru dan anak didik dalam interaksi edukatif sejak dari dahulu.

\section{Metode eksperimen}

Metode eksperimen ini memberikan kesempatan kepada para anak didik secara individu atau pun berkelompok untuk dilatih dalam melakukan suatu proses atau percobaan-percobaan. Metode ini bertujuan agar para anak didik tersebut berpikir kreatif, mandiri dan inovatif.

Metode pemberian tugas

Metode pemberian tugas di maksudkan para pendidik memberikan penjelasan dalam suatu bahasan lalu para pendidik tersebut memberikan tugas kepada para siswa untuk mengembangkan pembahasan yang telah di bahas, hal tersebut bertujuan agar para siswa berpikir dan memiliki wawasan yag luas.

Metode diskusi 
Metode ini adalah suatu alternatif dalam mengamati dan mencari jalan keluar dari suatu masalah melalui gagasan-gagasan yang di berikan para siswa, metode ini bertujuan untuk melatih para siswa agar berani dalam menyampaikan pendapat atau pun saran dan untuk mengembangkan pemikiran mereka.

\section{Metode latihan}

Metode latihan atau metode training yaitu metode yang menanamkan tentang kebiasaan-kesbiasaan tertentu dan untuk memelihara kebiasaan-kebiasaan baik terhadap anak. Metode latihan ini bertujuan untuk membentuk kebiasaan serta ketepatan dan kecepatan dalam pelaksanaan.

\section{Metode proyek}

Metode ini menggunakan cara mengajar dengan memberikan kesempatan kepada para siswa untuk menggunakan hal-hal yang ada di kehidupan sehari-hari sebagai bahan pendidikan. Metode ini bertujuan agar anak didik tertarik untuk terus belajar dan juga untuk membentuk pola pikir anak menjadi luas.

\section{Metode Drilling}

Menurut Roestiyah (2001), metode latihan adalah suatu cara mengajar dimana siswa melaksanakan kegiatankegiatan latihan agar siswa memiliki ketangkasan atau keterampilan yang lebih tinggi dari apa yang telah dipelajari.

Menurut Sagala (2003) Metode latihan (drill) atau metode training merupakan suatu cara mengajar yang baik untuk menanamkan kebiasaan-kebiasaan tertentu, selain itu sebagai sarana untuk memperoleh suatu ketangkasan, ketepatan, kesempatan dan keterampilan.
Dapat disimpulkan bahwa metode drilling merpakan suatu cara mengajar dengan memberikan latihan-latihan terhadap apa yang telah dipelajari mahasiswa sehingga memperoleh suatu keterampilan tertentu. Kata latihan mengandung arti bahwa sesuatu itu selalu diulang-ulang, akan tetapi bagaimanapun juga antara situasi belajar yang pertama dengan situasi belajar yang realistis, mahasiswa akan berusaha melatih keterampilannya. Bila situasi belajar itu diubah-ubah kondisinya sehingga menuntut respons yang berubah, maka keterampilan akan lebih disempurnakan.

Metode latihan biasanya digunakan dengan tujuan agar siswa:

Memiliki keterampilan motoris/gerak: seperti meghafalkan kata-kata, menulis, mempergunakan alat/ mempergunakan suatu benda.

Mengembangkan kecakapan intelek, seperti mengalikan, membagi, menjumlahkan, mengurangi, menarik akar dalam hitungang mencongak. Mengenal benda/bentuk dalam pelajaran matematika, ilmu pasti, ilmu kimia, tanda baca dan sebagainya.

Memeiliki kemampuan menghubungkan sesuatu keadaan dengan hal lain, seperti hubungan sebab akibat banyak hujan banjir, penggunaan lambang/simbol di dalam peta dan lainlain (Roestiyah, 2001).

Langkah-langkah Penggunaan Metode Latihan Terbimbing (Roestiyah, 2001)

1) Menjelaskan maksud dan tujuan latihan terbimbing pada siswa.

2) Guru harus lebih menekankan pada diagnosa, karena latihan permulaan belum bisa mengharapkan siswa mendapatkan keterampilan yang sempurna. 
3) Mengadakan latihan terbimbing sehingga timbul response siswa yang berbeda-beda untuk peningkatan keterampilan dan penyempunaan kecakapan siswa.

4) Memberi waktu untuk mengadakan latihan yang singkat agar tidak meletihkan dan membosankan dan guru perlu memperhatikan response siswa apakah telah melakukan latihan dengan tepat dan cepat.

5) Meneliti hambatan atau kesukaran yang dialami siswa dengan cara bertanya kepada siswa, serta memperhatikan masa latihan dengan mengubah situasi sehingga menimbulkan optimisme dan rasa gembira pada siswa yang dapat menghasilkan keterampilan yang baik.

6) Guru dan siswa perlu memikirkan dan mengutamakan proses-proses yang pokok dan tidak banyak terlibat pada hal-hal yang tidak diperlukan.

\section{Pendekatan Kontekstual}

Pendekatan CTL memberikan pengalaman bermaka secara langsung kepada siswa sekaligus memperhatikan faktor kebutuhan individual siswa dan peran guru. Contextual Learning (CTL) adalah sebuah sistem yang merangsang otak untuk menyusun pola-pola yang mewujudkan makna. CTL adalah suatu sistem pengajaran yang cocok dengan otak yang menghasilkan makna dengan menghubungkan muatan akademis dengan kehidupan sehari-hari siswa (Johnson, 2006: 65). Contextual Teaching and Learning adalah suatu pembelajaran yang menekankan kepada proses keterlibatan siswa secara penuh untuk dapat menemukan materi yang dipelajari dan menghubungkan dengan situasi kehidupan nyata sehingga siswa dapat menerapkannya daam kehidupan mereka.

Dalam konsep ini ada tiga hal yang harus dipahami, yaitu pertama, CTL menekankan kepada proses keterlibatan siswa untuk mencari materi artinya proses belajar diorientasikan pada proses pengalaman secara langsung. Kedua, CTL mendorong agar siswa dapat menemukan hubungan antara materi yang dipelajari dengan situasi kehidupan nyata. Ketiga, CTL mendorong siswa untuk dapat menerapkannya dalam kehidupan seharihari.

Artinya CTL bukan hanya mengharapkan siswa dapat memahami materi yang dipelajarinya akan tetapi bagaimana materi pelajaran itu dapat mewarnai perilakunya dalam kehidupan sehari-hari.

\section{Pemahaman atau Hasil Belajar}

Menurut Sunaryo (Komalasari, 2010:2) belajar merupakan suatu kegiatan dimana seseorang membuat atau menghasilkan suatu perubahan tingkah laku yang ada pada dirinya dalam pengetahuan, sikap, dan ketrampilan.

Gagne (Komalasari, 2010:12) mendefinisikan belajar sebagai suatu proses perubahan tingkah laku yang meliputi perubahan kecenderungan manusia seperti: sikap, minat, atau nilai dan perubahan kemampuannya yakni peningkatan kemampuan untuk melakukan berbagai jenis performance (kinerja)

Dari uraian diatas, dapat disimpulkan bahwa hasil perkuliahan adalah suatu proses perubahan tingkah laku dalam pengetahuan, sikap, dan ketrampilan yang diperoleh dalam jangka waktu yang lama. 
Belajar menurut Gagne (dalam Sugiyanto, 2009:124) merupakan sebuah sistem yang di dalamnya terdapat berbagai unsur yang saling kait mengkait sehingga menghasilkan perubahan perilaku. Beberapa unsur dimaksud adalah sebagai berikut:

\section{a. Pembelajar}

Pembelajar adalah peserta didik,warga belajar, peserta pelatihan, atau mahasiswa

b. Rangsangan (stimulus)

Peristiwa yang merangsang penginderaan pembelajaran disebut situasi stimulus. Agar pembelajar mampu belajar optimal, is harus memfokuskan pada stimulus tertentu yang diminati.

\section{c. Memori}

Memori pembelajar berisi berbagai kemampuan yang berupa pengetahuan, ketrampilan, dan sikap yang dihasilkan dari aktifitas belajar sebelumnya.

d. Respon

Tindakan yang dihasilkan dari aktualisasi memori disebut respon. Pembelajar yang sedang mengamati stimulus, maka memori yang ada di dalam dirinya kemudian memberikan respon terhadap stimulus tersebut.

Adapun nilai yang telah dicapai atau diperoleh (dari yang telah dilakukan dan dikerjakan oleh seseorang) disebut hasil. Hasil perkuliahan digunakan untuk pencapaian tingkat keberhasilan suatu tujuan karena sesuatu telah dilakukan oleh seseorang.

\section{METODE PENELITIAN}

a. Jenis Penelitian

Jenis penelitian yang digunakan dalam penelitian ini adalah penelitian kuantitatif deskriptif. Data hasil penelitian kuantitatif akan di deskripsikan berupa kata-kata dan akan dipaparkan sesuai dengan data yang terkumpul dan di analisis secara induktif. Dalam penelitian ini peneliti menggambarkan melalui beberapa tahapan, diantaranya a)observasi keterlaksanaan pembelajaran menggunakan metode drilling yang berorientasi pada pendekatan kontekstual b)observasi aktifitas pembelajaran mahasiswa menggunakan metode drilling yang berorientasi pada pendekatan kontekstual c)mengukur hasil capaian d)analisis hasil capaian e)gambar diagram.

b. Metode Pengambilan Data

Teknik pengumpulan data dilakukan dengan cara sebagai berikut:

1) Lembar observasi keterlaksanaan RPP menggunakan metode drilling yang berorientasi pendekatan kontekstual sebagai acuan untuk mengukur keterlaksanaan perkuliahan menggunakan metode drilling yang berorientasi pendekatan kontekstual.

2) Lembar observasi aktifitas mahasiswa dalam prosesm perkuliahan menggunakan metode drilling yang berorientasi pendekatan kontekstual sebagai acuan untuk mengukur aktifitas perkuliahan menggunakan metode drilling yang berorientasi pendekatan kontekstual.

3) Tes hasil perkuliiahan

Pemberian tes sesuai dengan indikator dan tujuan yang telah disusun peneliti. Tes dilakukan setelah proses perkuliahan menggunakan metode drilling yang berorientasi pendekatan kontekstual untuk mengetahui pemahaman mahasiswa dalam menganalisis materi.

dalam penelitian ini antara lain: 


\section{c. Analisis Data}

Mendeskripsikan data tes hasil perkuliahan mahasiswa PGSD sesuai dengan ketuntasan hasil belajar individual dan klasikal. Rumus yang dipakai untuk menetapkan nilai akhir sebagai berikut:

$$
\mathrm{M}=\left(\sum \mathrm{x}\right) / \mathrm{N}
$$

Keterangan :

M : mean (nilai rata-rata)

$\sum \mathrm{x}$ : Jumlah nilai seluruh siswa

$\mathrm{N}$ : Jumlah siswa

Hasil belajar individual dengan nilai minimal B.

\section{HASIL DAN PEMBAHASAN}

Hasil Tes Mahasiswa Sebelum dan Sesudah Menggunakan Metode Drilling Yang Berorientasi Pendekatan Kontekstual

\begin{tabular}{|c|c|c|c|}
\hline \multirow[t]{2}{*}{ No. } & \multirow[t]{2}{*}{ Somat } & \multicolumn{2}{|c|}{ Fash 795} \\
\hline & & Bequlum & Sardw \\
\hline 1 & NU2. CALYA NLNGSEH & 78 & 84 \\
\hline 2 & MALIRHATLL MASNU AH & 30 & 87 \\
\hline 3 & FANY NUR ATIOOO & 75 & 84 \\
\hline 4 & UCINLRUI DIDAYATI & 78 & 8 \\
\hline 5 & YLNITA RALMANANAR & 75 & 84 \\
\hline 6 & ACRMAD SYAFII & 80 & 8 \\
\hline$T$ & LIA RTTAN DZATIWI & 75 & 80 \\
\hline 8 & GNILAS NGSTHA DRATTWT & $\pi$ & 86 \\
\hline I & DEV ANTIKA WIDFAWAIt & 78 & 8 \\
\hline III & A.MMSD R.OY IANUAR DR.ATAMA & 78 & 8 \\
\hline 11 & CHLARA AYU OKTA TRIBNANI & 80 & 8 \\
\hline 12 & WhIRA MANGQAR RANI & 78 & 87 \\
\hline 13 & NILAM CAWYAFERDANA & 78 & 85 \\
\hline$\frac{14}{14}$ & EKXYY WITDYA NURDVYANTI & 80 & 8 \\
\hline 15 & ARUR RORMAR & 85 & 80 \\
\hline It & BIDAN LILIK WIDLSWATI & 75 & 8 \\
\hline 17 & LIBA LUSITHA WAHYU DYANI & 77 & 药 \\
\hline 18 & FIRA NUR. DIDAYATI & 78 & 8 \\
\hline II & RIBDLANA XESTUNINGTYAS & 78 & 84 \\
\hline 211 & ANITA RANWAWWATI & 75 & 86 \\
\hline 21 & ROSBI AJENG VZATTWI & 75 & 84 \\
\hline 22 & SULALMANAD NAJIB WAMIDUS SALAM & 75 & 86 \\
\hline 23 & CINDY AMINATU Z ZAKTYAR & 77 & 8 \\
\hline 24 & DNNI SETIYOWANTI & 78 & 85 \\
\hline 25 & ARROBI ATUS SROLIRLAM & 75 & (日) \\
\hline $2 \mathrm{th}$ & DEWT ASTUTER & 75 & 84 \\
\hline 27 & RICKY EFENDI YUSUF SANTOSO & 78 & 86 \\
\hline 28 & ADE WUTRI & 73 & 85 \\
\hline 29 & ARIF DWI SLDR.AIAD & 76 & 89 \\
\hline 30 & ERA WLAYANII & 76 & 86 \\
\hline 31 & HENVANBIB WHISTIE BNIRAWANLATI & 75 & 84 \\
\hline 32 & YLYUN SRIWAWVLNI & 75 & 84 \\
\hline 33 & STNTA MARET ANGQRARI] & 73 & 8 \\
\hline 34 & MUCDAMAD RABR AFIF & 80 & 84 \\
\hline 35 & RNENTA AIENG RIZSY D. & 75 & 8 \\
\hline 36 & M. WISBCL MAULANA FIRDAUSB & 73 & 84 \\
\hline 37 & DWI ANISA AMBBARWATI- & 73 & 84 \\
\hline 38 & AMALLA FITR RODXKAWATI & 78 & 8 \\
\hline 39 & SOH ARIZAL ARIFF. & 72 & 84 \\
\hline 40 & ENDARRATNA & 72 & 84 \\
\hline 41 & FITRLA WLLAN SARE & 70 & 85 \\
\hline 42 & DEWT KLALLMATUL AFIFAH & 78 & 86 \\
\hline Keta & atis & 70 & 0 \\
\hline
\end{tabular}

Dapat dilihat rata-rata hasil tes mahasiswa sebelum menggunaan metode drilling yang berorientasi pendeatan kontestal dengan skor 70 yang dikategorikan baik. Sementara rata-rata hasil tes mahasiswa sesudah menggunaan metode drilling yang berorientasi pada pendekatan kontekstual dengan skor 90 yang dikategoran sangat baik. Maka dapat disimpulkan bahwa terdapat peningkatan pemahaman yang diukur melalui hasil belajar mahasiswa sebelum dan sesudah menggunaan metode drilling yang berorieentasi pada pendeatan kontestual.

\section{KESIMPULAN}

Dari hasil tesebut dapat disimpulkan bahwa terdapat peningkatan pemahaman mahasiswa yang diukur melalui tes hasil belajar sebelun dan sesudah menggunkan metode drilling yang berorientasi pada pendekatan kontekstual

\section{REFERENSI}

Aqib, Zainal. 2009. Penelitian Tindakan Sekolah. Bandung: Yrama Widya

Johnson, Elaine. 2006. Contextual Teaching and Learning. Bandung: MLC

Munandir. 1987. Rancangan Sistem Pengajaran. Jakarta:

Departermen Pendidikan dan Kebudayaan.

Munthe, Bermawi. 2009. Desain Pembelajaran. Yogyakarta: Pustaka Insan Madani

Komalasari, Kokom. 2010. Pembelajaran Kontekstual. Bandung: PT.Refika Aditama

Lorin W, Anderson, dkk. 2010. Kerangka Landasan untuk Pembelajaran, Pengajaran, dan Asesmen. Yogyakarta: Puataka Pelajar 
Sudjana, Nana. 2009. Penilaian Hasil

Proses Belajar Mengajar.

Bandung: PT. Remaja

Rosdakarya

Suyomo. 2011. Belajar dan

Pembelajaran. Bandung:

Remaja Rosdakarya

Sugiyanto. 2010. Model-model

Pembelajaran Inovatif.

Surakarta: Yuma Pustaka

Suwarno, Wiji. 2006. Dasar-dasar

Ilmu Pendidikan. Jogjakarta:

Ar-ruzz media

Trianto. 2009. Mendesain Model

Pembelajaran Inovatif-

Progresif. Jakarta:Kencana 